\title{
Stigma Experiences in People with Chronic Obstructive Pulmonary Disease: An Integrative Review
}

\author{
Seoyoon Woo $\mathbb{D}^{1}$ \\ Weijiao Zhou $\mathbb{D}^{2}$ \\ Janet L Larson $\mathbb{D}^{2}$ \\ 'University of North Carolina \\ Wilmington, School of Nursing, \\ Wilmington, NC, 28403-5995, USA; \\ ${ }^{2}$ University of Michigan, School of \\ Nursing, Ann Arbor, MI, 48I09, USA
}

Correspondence: Seoyoon Woo

University of North Carolina Wilmington,

School of Nursing, McNeill Hall 3089, 60I

South College Road, Wilmington, NC,

28403-5995, USA

Tel $+(910) 962-3843$

Email woos@uncw.edu
Background: People with chronic obstructive pulmonary disease (COPD) are stigmatized by smoking history. Although little is known about COPD-related stigma, it can adversely affect self-management and quality of life.

Objective: To synthesize relevant scientific literature exploring stigma experiences and their impacts on people with COPD.

Methods: CINAHL/PsycINFO/PubMed/Scopus were searched for relevant studies. Findings were organized using Major et al's conceptual model.

Results: Fifteen studies documented COPD-related stigma processes: enacted, felt, internalized, and anticipated. Moderating factors included visibility, origin, and illness perception. Individual-level stigma responses included emotional distress, limited social interactions, and negative effects on medication adherence and help-seeking. Social/community-level stigma experiences included healthcare provider and employer behaviors. Smoking is interwoven throughout all domains of stigma processes and responses to stigma.

Conclusion: Substantial evidence documents processes, moderating factors, and individual and social/community responses to the complex phenomenon of COPD-related stigma; however, prevalence of COPD-related stigma and its health effects are unclear.

Keywords: chronic obstructive pulmonary disease, COPD, stigma, shame, smoking, integrative review

\section{Introduction}

People who suffer from stigmatized chronic health conditions ${ }^{1}$ are often devalued and, as a result, are less likely to access and obtain medical care for their symptoms ${ }^{2}$ and more likely to experience delays in diagnosis. ${ }^{1}$ Due to its link to smoking, chronic obstructive pulmonary disease (COPD) is one of these stigmatized chronic conditions. ${ }^{3,4}$ Because most people who develop COPD have a smoking history, ${ }^{5}$ people with COPD are generally assumed to be smokers and, therefore, experience stigmatization by others. ${ }^{3}$ This integrative review synthesizes the existing evidence that describes stigma-related experiences and their impacts on people with COPD.

\section{Smoking-Related Stigma}

Ironically, smoking-related stigma has arisen from strategies to raise social awareness about the harmful effects of smoking. ${ }^{6}$ The 1964 Surgeon General's report played a pioneering role in educating the general public about the negative 
consequences of smoking and contributed to declines in overall smoking rates. ${ }^{7}$ This report also provided the basis for policies that promote smoke-free environments by restricting smoking in public spaces to isolated areas, as well as for smoking-cessation campaigns, programs, and interventions. ${ }^{8}$ Although these efforts have reduced smoking-related disease and death, they have also played a profound role in stigmatizing both smoking and smokers. ${ }^{9,10}$

As a result, smokers have increasingly encountered smoking-related discrimination in their daily lives. People who continue to smoke are seen as indifferent to their own health and the health of others who inhale secondhand smoke. Because of this, they are shunned by non-smokers. ${ }^{9-11}$ Smokers also bear the cost of increased taxes on tobacco products, which can be especially stressful for low-income smokers. ${ }^{12}$ Additionally, many healthcare providers have unfavorable attitudes towards people with smoking-related lung diseases, ${ }^{9,13}$ which may negatively affect the willingness of people with COPD to seek healthcare.

Because the way people think about and behave toward an individual with a chronic health condition can be intensified by the perceived origins of the condition, ${ }^{14,15}$ the stigma now attached to smoking has broadened to people with COPD, ${ }^{16}$ which is perceived as a preventable disease. Thus, people who develop COPD are frequently viewed as being responsible for their own condition. This generates feelings of self-blame and guilt in people with COPD ${ }^{15,17}$ and can affect multiple aspects of health and wellbeing. $^{3,4,18-23}$

A substantial body of research on the broader issue of health-related stigma exists, but research on COPD-related stigma is still relatively new. This integrative review of existing research on COPD-related stigma advances the science by deepening understanding of stigma-related experiences in people with COPD.

\section{Conceptual Framework}

The components of stigma can be described theoretically in terms of stigma processes, moderating factors that influence stigma processes, and the individual and social/ community level responses to stigma experiences as described by Major et al's conceptual model of the effects of stigma processes on health. ${ }^{24}$ According to this model, stigma is triggered by a socially conferred mark or stigmatized mark that separates the stigmatized group from the non-stigmatized group via social norms. The effect of the socially conferred mark develops in different ways and is affected by a variety of moderating factors (eg, dimensions of the mark, individual and environmental characteristics). Dimensions of the mark have been well identified and include concealability (whether the stigmatized mark is visible), course (whether the stigmatized mark has faded with the passage of time), disruptiveness (whether features of the stigmatized mark hinder interpersonal relationships), aesthetic qualities (whether the stigmatized mark is physically repellent), origin (whether a stigmatized individual is responsible for the stigmatized mark), peril (whether the features of the stigmatized mark are dangerous, such as contagiousness), ${ }^{14}$ and collectivity (whether the stigmatized mark is affected by a collective identity, such as LGBT, or by a personal identity). ${ }^{24}$ These moderating factors play a role in determining the character, intensity, pervasiveness, and consequences of stigmatization. ${ }^{24}$ For example, the perception of smoking as a voluntary, controllable behavior has led people to perceive COPD as self-inflicted; this increases the severity of the stigma processes.

Stigma processes refer to individual, social, and/or structural processes that elicit distressing responses from the socially conferred mark. For the purpose of this model, stigma processes consist of four stigmas: enacted stigma, felt stigma (also called perceived stigma), self-stigma (also called internalized stigma), and anticipated stigma; these stigmas are interrelated. Enacted stigma refers to unfair treatment or discrimination against the stigmatized group that is based on negative social and cultural beliefs, and feelings. Felt stigma refers to the stigmatized group's perception of unfairness or discrimination associated with their stigmatized status. Self-stigma refers to the individual's adoption of his or her stigmatized status. Anticipated stigma refers to the apprehension of encountering unfairness or discrimination because of the stigmatized status.

Exposure to these stigma processes creates cognitive, affective, behavioral, and physiological responses on an individual, social, and community level, all of which gradually cause deteriorating health outcomes. Affective responses, such as anxiety, anger, or shame, can increase the likelihood of higher-risk health behaviors. Stigma experiences can also affect cognitive control ability (cognitive responses) or self-regulatory ability (behavioral responses) that can intensify or mitigate the effects of stigma experiences on health. 


\section{Materials and Methods}

We employed an integrative approach that is suitable for selecting relevant studies, synthesizing findings from diverse primary research methods, and providing varied perspectives and understanding of a phenomenon of interest. ${ }^{25}$ Ethical approval was not needed to conduct this review.

\section{Search Strategies}

Four electronic databases-CINAHL, PsycINFO, PubMed, and Scopus - were searched for articles published from their inceptions through December 2020. After consultation with a health sciences librarian, the following combination of search terms was used to capture the target population: "chronic obstructive pulmonary disease" OR "COPD." Stigma search terms included "social stigma" OR "shame" OR "stigma" (see Appendix 1).

\section{Study Selection}

Two authors (SW and JLL) independently reviewed titles and abstracts to ensure that they met inclusion criteria. During title/abstract review, studies were retained for further review if they 1) were published in peer-reviewed journals; 2) were original studies, including either quantitative or qualitative designs; 3 ) described characteristics of COPD-related stigma; 4) were published in English; and 5) included adults with COPD (18 years and over), irrespective of Global Initiative for Obstructive Lung Disease (GOLD) COPD stage and severity. Non-original studies, such as reviews, systematic reviews, metaanalyses, or meta-syntheses, as well as case studies, case reports, comments, letters, editorials, biographies, handbooks, study protocols, and treatment guidelines were excluded. After reviewing the full text of all studies meeting the initial title/abstract review, the decision was made to exclude studies with minor incidental findings related to stigma, studies with combined findings of two or more health conditions related to stigma, as well as studies that only explored the perspectives of healthcare providers and/ or the general population. Shaw's checklists, ${ }^{26}$ which consist of 18 items for quantitative studies and 15 items for qualitative studies, were used to assess the methodological quality of all included studies (seeAppendices 2 and 3). Each checklist item was graded as good (2), fair (1), or poor (0), based on the extent to which the individual study met each criterion. Scores were calculated as a percentage of the highest possible score for each study.

\section{Search Outcome}

The search of the four electronic databases yielded 343 studies, including 76 duplicates. After the 267 unique articles' titles and abstracts were screened, 34 studies remained for full-text review. Of those, 19 were excluded because they a) combined findings of two or more health conditions (eg, stigma experiences in people with COPD and in those with asthma), b) did not focus on COPDrelated stigma (ie, incidental findings of stigma), c) were not an eligible type of study (ie, commentary), or d) did not collect data from people with COPD. Finally, 15 articles were reviewed (see Figure 1).

\section{Data Analysis}

In this review, Major et al's conceptual model of stigma processes on health ${ }^{24}$ was guided for both data analysis and presentation of the findings. One author (SW) reviewed the included studies and extracted the following data: year and location of publication, sample characteristics, type of study design, and main findings (see Table 1). A second author (WZ) reviewed and verified the extracted data for accuracy. Through an iterative process, data were reduced, analyzed, and synthesized using thematic analysis. ${ }^{25,27}$ The included studies were explored for evidence describing COPD-related stigma experiences, and the relevant findings were identified and coded. The codes were reassembled to find themes and sub-themes. Then, themes and sub-themes were organized by the constructs in the conceptual model. For the single study ${ }^{28}$ that used a mixed-method design, we focused solely on its qualitative phase so that we could synthesize and organize all the studies' findings using Major et al's conceptual model. ${ }^{24}$ The NVivo software program ${ }^{29}$ was used to aid in sorting and organizing data.

\section{Results}

\section{Overview of the Studies}

Of the included studies $(\mathrm{n}=15), 14$ used a qualitative research design ${ }^{30-43}$ and one a mixed-method research design. ${ }^{28}$ Ten studies collected data using individual interviewing, one used focus group interviewing, ${ }^{40}$ three used both individual and focus group interviewing, ${ }^{32,39,43}$ and one used individual interviewing along with a selfadministered questionnaire. ${ }^{28}$ The methodological quality of the qualitative studies $(\mathrm{n}=14)^{30-43}$ ranged from $67 \%$ to $90 \%$ and the mixed-method study ${ }^{28}$ scored $70 \%$ for the qualitative phase and $95 \%$ for the quantitative phase. ${ }^{26}$ 


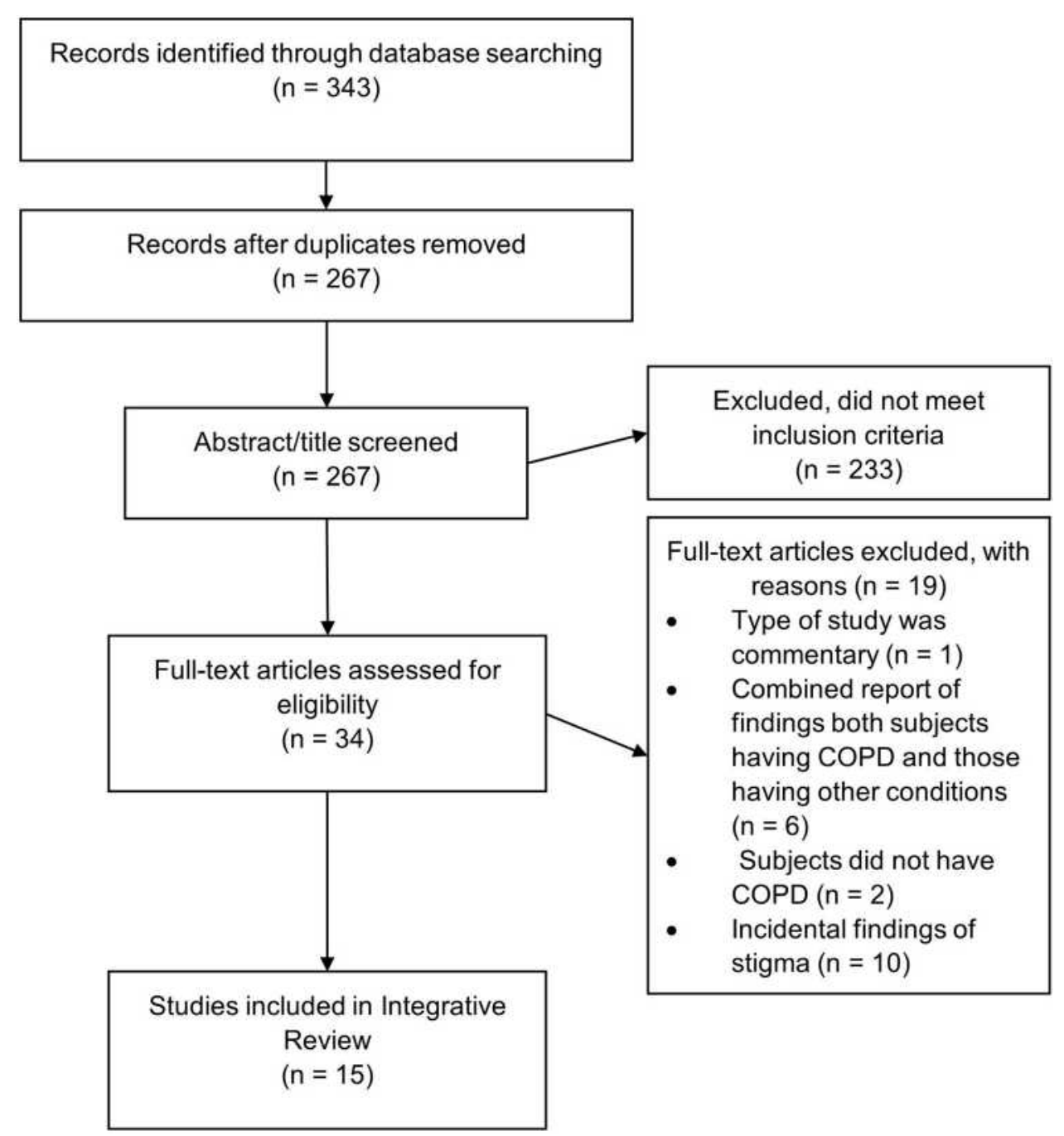

Figure I Flow diagram of integrative review.

Abbreviation: COPD, chronic obstructive pulmonary disease.

Four studies were conducted in the United Kingdom, ${ }^{35,37,40,43}$ three in Sweden, ${ }^{30,41,42}$ two in the United States, ${ }^{31,33}$ two in Iceland, ${ }^{32,38}$ one in Canada, ${ }^{28}$ one in Korea, ${ }^{39}$ one in Norway, ${ }^{36}$ and one in Switzerland. ${ }^{34}$ Ten studies included both men and women; ${ }^{28,31,32,34-36,40-43}$ the other five focused on more restricted groups: women only, ${ }^{38}$ men only, ${ }^{39}$ those newly diagnosed, ${ }^{30}$ people on long-term supplemental oxygen, ${ }^{33}$ and people who refused a referral to a pulmonary rehabilitation program after experiencing an acute exacerbation. ${ }^{37}$ The numbers of participants ranged from $\operatorname{six}^{37,39}$ to $70 .^{28}$

Four studies focused on exploring COPD-related stigma $^{28,31,32,36}$ and eleven identified meaningful findings of COPD-related stigma while exploring the broader experiences of having COPD. ${ }^{30,33-35,37-43}$

\section{Findings Organized by the Conceptual Framework Socially Conferred Mark}

Smoking is identified as the primary socially conferred mark of COPD across the included studies. Because smoking is perceived as an "idiotic" habit ${ }^{31}$ whose effects are harmful, it is socially unacceptable. ${ }^{38,42}$ People who smoke and have COPD cannot avoid personal culpability. ${ }^{28,30-32,36-38,41}$ One study observed that smelling like smoke makes the individual with COPD vulnerable to public criticism. ${ }^{38}$

\section{Stigma Processes}

In the included studies, the enacted stigma, felt stigma, internalized stigma, and anticipated stigma were found as stigma processes for COPD. 
Table I Characteristics of Included Studies

\begin{tabular}{|c|c|c|c|c|c|}
\hline $\begin{array}{l}\text { Author, Year, } \\
\text { Location }\end{array}$ & Research Aim & Study Design & $\begin{array}{l}\text { Sample } \\
\text { Characteristics }\end{array}$ & Main Findings & $\begin{array}{l}\text { Methodological } \\
\text { Quality }\end{array}$ \\
\hline $\begin{array}{l}\text { Arne, Emtner, } \\
\text { Janson and Wilde- } \\
\text { Larsson, }{ }^{30} 2007 \text {, } \\
\text { Sweden }\end{array}$ & $\begin{array}{l}\text { To gain an understanding of } \\
\text { patients' perspectives and } \\
\text { perceptions of COPD at the } \\
\text { time of diagnosis }\end{array}$ & $\begin{array}{l}\text { Qualitative study } \\
\text { using grounded } \\
\text { theory }\end{array}$ & $\begin{array}{l}\text { People who were newly } \\
\text { diagnosed with COPD } \\
\text { or with suspected } \\
\text { COPD }(N=10) \\
\text { - Age (mean) }=63 \text { yrs } \\
\text { - Smoking status: for- } \\
\text { mer }(n=6) \text {; current } \\
(n=4)\end{array}$ & $\begin{array}{l}\text { Becoming physically } \\
\text { restricted is a key indicator of } \\
\text { developing disease and } \\
\text { getting a diagnosis was crucial } \\
\text { for the patient. Shame was } \\
\text { apparent throughout the } \\
\text { interviews and impeded } \\
\text { study participants' taking } \\
\text { action. }\end{array}$ & $80.0 \%$ \\
\hline $\begin{array}{l}\text { Berger, Kapella and } \\
\text { Larson, }{ }^{31} 201 \mathrm{I}, \\
\text { United States }\end{array}$ & $\begin{array}{l}\text { To describe social changes } \\
\text { and experiences of stigma } \\
\text { from the perspective of } \\
\text { people with moderate to } \\
\text { severe COPD }\end{array}$ & $\begin{array}{l}\text { Descriptive, } \\
\text { qualitative study }\end{array}$ & $\begin{array}{l}\text { People with moderate } \\
\text { or severe COPD ( } N= \\
\text { I6) } \\
\text { - Age (mean) }=70 \text { yrs } \\
\text { - Smoking status: former } \\
\text { or current }(n=16)\end{array}$ & $\begin{array}{l}\text { Study participants were } \\
\text { aware of the potential for } \\
\text { stigma related to COPD. } \\
\text { Noted themes included the } \\
\text { prevalence of blame related } \\
\text { to smoking, both from } \\
\text { others, including health care } \\
\text { providers, and from } \\
\text { themselves. }\end{array}$ & $80.0 \%$ \\
\hline $\begin{array}{l}\text { Bragadottir, } \\
\text { Halldorsdottir, } \\
\text { Ingadottir and } \\
\text { Jonsdottir, }{ }^{32} 2018, \\
\text { Iceland }\end{array}$ & $\begin{array}{l}\text { To gain a better } \\
\text { understanding of having } \\
\text { COPD from the lived } \\
\text { experience of patients and } \\
\text { their families }\end{array}$ & $\begin{array}{l}\text { Qualitative, } \\
\text { phenomenological } \\
\text { study }\end{array}$ & $\begin{array}{l}\text { i) People with COPD ( } n \\
=22) \\
\text { - Age (range) }=51-68 \\
\text { yrs } \\
\text { - Smoking status: never } \\
(n=1) \text {; former }(n= \\
\text { I7); current }(n=4) \\
\text { ii) Families }(n=15)\end{array}$ & $\begin{array}{l}\text { Learning about and } \\
\text { becoming diagnosed with } \\
\text { COPD was a long and } \\
\text { arduous process. Study } \\
\text { participants did not realize } \\
\text { the imminent threat of } \\
\text { COPD to their life. }\end{array}$ & $66.7 \%$ \\
\hline $\begin{array}{l}\text { Earnest, }^{33} 2002, \\
\text { United States }\end{array}$ & $\begin{array}{l}\text { To describe and explain the } \\
\text { patterns of adherence to } \\
\text { supplemental oxygen }\end{array}$ & $\begin{array}{l}\text { Descriptive, } \\
\text { qualitative study of } \\
\text { a case series }\end{array}$ & $\begin{array}{l}\text { People with COPD who } \\
\text { use long-term } \\
\text { supplemental oxygen (N } \\
=27 \text { ) } \\
\text { - Age (mean) = } 67 \mathrm{yrs} \\
\text { - Smoking status: not } \\
\text { reported }\end{array}$ & $\begin{array}{l}\text { Three distinct patterns of } \\
\text { adherence to supplemental } \\
\text { oxygen theory were as- } \\
\text { needed use, part-item use, and } \\
\text { full-time use. Adherence to } \\
\text { oxygen tended to increase } \\
\text { with time and was often } \\
\text { associated with significant } \\
\text { personal compromises. }\end{array}$ & $83.3 \%$ \\
\hline $\begin{array}{l}\text { Fusi-Schmidhauser, } \\
\text { Froggatt and } \\
\text { Preston, }{ }^{34} 2020, \\
\text { Switzerland }\end{array}$ & $\begin{array}{l}\text { To explore the experiences } \\
\text { of patients and informal } \\
\text { carers in living with } \\
\text { advanced COPD as well as } \\
\text { their awareness about } \\
\text { palliative care provision in } \\
\text { advanced COPD }\end{array}$ & $\begin{array}{l}\text { Qualitative, } \\
\text { descriptive study }\end{array}$ & $\begin{array}{l}\text { i) People with COPD } \\
\text { (Stages III and IV) }(n= \\
\text { 20) } \\
\text { - Age (mean) = } 69 \text { yrs } \\
\text { (range: } 63-76 \text { yrs) } \\
\text { - Smoking status: for- } \\
\text { mer }(n=9) \text {; current } \\
(n=I I) \\
\text { ii) Informal carers ( } n= \\
\text { 20) }\end{array}$ & $\begin{array}{l}\text { Daily activities were highly } \\
\text { influenced by COPD } \\
\text { symptoms. A range of } \\
\text { psychological challenges } \\
\text { along the disease trajectory, } \\
\text { with feelings of guilt, } \\
\text { discrimination and blame, } \\
\text { were reported. Most of the } \\
\text { participants had no } \\
\text { knowledge of palliative care. }\end{array}$ & $83.3 \%$ \\
\hline
\end{tabular}

(Continued) 
Table I (Continued).

\begin{tabular}{|c|c|c|c|c|c|}
\hline $\begin{array}{l}\text { Author, Year, } \\
\text { Location }\end{array}$ & Research Aim & Study Design & $\begin{array}{l}\text { Sample } \\
\text { Characteristics }\end{array}$ & Main Findings & $\begin{array}{l}\text { Methodological } \\
\text { Quality }\end{array}$ \\
\hline $\begin{array}{l}\text { Gysels and } \\
\text { Higginson, }{ }^{35} 2008, \\
\text { United Kingdom }\end{array}$ & $\begin{array}{l}\text { To explore the experience } \\
\text { of breathlessness through } \\
\text { patients' accounts of their } \\
\text { interactions with services }\end{array}$ & $\begin{array}{l}\text { Qualitative study } \\
\text { using grounded } \\
\text { theory }\end{array}$ & $\begin{array}{l}\text { People with moderate } \\
\text { or severe COPD ( }= \\
\text { 18) } \\
\text { - Age (range) }=52-78 \\
\text { yrs } \\
\text { - Smoking status: not } \\
\text { reported }\end{array}$ & $\begin{array}{l}\text { Slow and surreptitious } \\
\text { onset of breathlessness, } \\
\text { social stigma toward } \\
\text { breathlessness, and the way } \\
\text { breathlessness is addressed } \\
\text { by institutions influenced } \\
\text { the low access to services } \\
\text { by people with COPD. }\end{array}$ & $90.0 \%$ \\
\hline $\begin{array}{l}\text { Halding, Heggdal and } \\
\text { Wahl, }^{36} 20 \mathrm{II}, \\
\text { Norway }\end{array}$ & $\begin{array}{l}\text { To understand how patients } \\
\text { with COPD experience } \\
\text { daily life in a society with } \\
\text { a heavy emphasis on } \\
\text { tobacco control }\end{array}$ & $\begin{array}{l}\text { Qualitative, } \\
\text { descriptive, } \\
\text { longitudinal study }\end{array}$ & $\begin{array}{l}\text { People with COPD (N } \\
=18) \\
\text { - Age (range) }=52-81 \\
\text { yrs } \\
\text { - Smoking status: never } \\
(n=2) ; \text { former }(n= \\
\text { II); current }(n=5)\end{array}$ & $\begin{array}{l}\text { Because of self-blame and } \\
\text { society's stigmatization, } \\
\text { study participants } \\
\text { experienced feelings of } \\
\text { disgrace through subtle } \\
\text { blame and a lack of support } \\
\text { from their social network, } \\
\text { health care encounters, and } \\
\text { the larger society. }\end{array}$ & $73.3 \%$ \\
\hline $\begin{array}{l}\text { Harrison, } \\
\text { Robertson, Apps, } \\
\text { C. Steiner, Morgan } \\
\text { and Singh, }{ }^{37} 2015 \text {, } \\
\text { United Kingdom }\end{array}$ & $\begin{array}{l}\text { To explore how patients } \\
\text { who refuse a referral to } \\
\text { Pulmonary Rehabilitation } \\
\text { (PR) appraise acute } \\
\text { exacerbations of COPD }\end{array}$ & $\begin{array}{l}\text { Qualitative, } \\
\text { descriptive study }\end{array}$ & $\begin{array}{l}\text { People recently } \\
\text { hospitalized with an } \\
\text { acute exacerbation of } \\
\text { COPD }(\mathrm{N}=6) \\
\text { - Age (mean) }=75.8 \\
\text { yrs } \\
\text { - Smoking status: for- } \\
\text { mer }(n=5) \text {; current } \\
(n=1)\end{array}$ & $\begin{array}{l}\text { Perceived personal } \\
\text { culpability caused people } \\
\text { with COPD to feel } \\
\text { unworthy of dedicated care } \\
\text { and to be sensitized to their } \\
\text { interactions with health care } \\
\text { professionals. }\end{array}$ & $80.0 \%$ \\
\hline $\begin{array}{l}\text { Harrison, } \\
\text { Robertson, } \\
\text { Goldstein and } \\
\text { Brooks, }{ }^{28} 2017, \\
\text { Canada }\end{array}$ & $\begin{array}{l}\text { - To gain an understanding } \\
\text { of the extent to which } \\
\text { self-conscious emotions } \\
\text { are expressed } \\
\text { - To examine any associa- } \\
\text { tions between self- } \\
\text { conscious emotions and } \\
\text { adverse health outcomes } \\
\text { - To compare self- } \\
\text { conscious emotions in } \\
\text { people with COPD to } \\
\text { healthy controls }\end{array}$ & $\begin{array}{l}\text { Mixed methods: } \\
\text { sequential } \\
\text { exploratory design }\end{array}$ & $\begin{array}{l}\text { Quantitative Phase } \\
\text { - COPD only }(n=15) \\
\text { - Age (mean) }=73 \text { yrs } \\
(n=13) \text {; current }(n=2) \\
\text { Quantitative Phase } \\
\text { I) COPD }(n=70) \\
\text { - Age (mean) }=70.8 \\
\text { yrs } \\
\text { - Smoking status: for- } \\
\text { mer ( } n=66) \text {; cur- } \\
\text { rent ( } n=4) \\
\text { ii) Healthy controls ( } \\
=63) \\
\text { - Age (mean) }=66.2 \\
\text { yrs } \\
\text { - Smoking status: never } \\
\text { ( } n=47) ; \text { former }(n= \\
\text { II); current }(n=3)\end{array}$ & $\begin{array}{l}\text { Self-conscious emotions } \\
\text { were associated with } \\
\text { reduced mastery, } \\
\text { heightened emotions, and } \\
\text { elevated anxiety and } \\
\text { depression (all } p<0.00 \mathrm{I} \text { ). } \\
\text { Individuals with COPD } \\
\text { reported lower self- } \\
\text { compassion, higher shame, } \\
\text { and less pride than healthy } \\
\text { controls (all } p \leq 0.01 \text { ). }\end{array}$ & $\begin{array}{l}\text { - Qualitative } \\
\text { phase: } 70.0 \% \\
\text { - Quantitative } \\
\text { phase: } 95.0 \%\end{array}$ \\
\hline
\end{tabular}

(Continued) 
Table I (Continued).

\begin{tabular}{|c|c|c|c|c|c|}
\hline $\begin{array}{l}\text { Author, Year, } \\
\text { Location }\end{array}$ & Research Aim & Study Design & $\begin{array}{l}\text { Sample } \\
\text { Characteristics }\end{array}$ & Main Findings & $\begin{array}{l}\text { Methodological } \\
\text { Quality }\end{array}$ \\
\hline $\begin{array}{l}\text { Jonsdottir and } \\
\text { Jonsdottir, }{ }^{38} 2007, \\
\text { Iceland }\end{array}$ & $\begin{array}{l}\text { To illuminate the experience } \\
\text { of repeatedly relapsing to } \\
\text { smoking }\end{array}$ & $\begin{array}{l}\text { Qualitative, } \\
\text { phenomenological } \\
\text { study }\end{array}$ & $\begin{array}{l}\text { Females with COPD } \\
\text { who had relapsed to } \\
\text { smoking three or more } \\
\text { times }(\mathrm{N}=7) \\
\text { - Age (mean) }=55 \text { yrs } \\
\text { - Smoking status: } \\
\text { current }(\mathrm{n}=7)\end{array}$ & $\begin{array}{l}\text { Smoking-related lung } \\
\text { disease (ie, COPD) controls } \\
\text { the life of study participants } \\
\text { on a very fundamental level. } \\
\text { Their capacity to refrain } \\
\text { from smoking was limited } \\
\text { and they vacillated between } \\
\text { wanting and not wanting to } \\
\text { stop. }\end{array}$ & $66.7 \%$ \\
\hline $\begin{array}{l}\text { Kim, Ko and Choi, }{ }^{39} \\
\text { 2020, Korea }\end{array}$ & $\begin{array}{l}\text { To qualitatively explore the } \\
\text { perceptions and experiences } \\
\text { of disease among Korean } \\
\text { male older adults with } \\
\text { COPD }\end{array}$ & $\begin{array}{l}\text { Qualitative, } \\
\text { descriptive study }\end{array}$ & $\begin{array}{l}\text { Male with COPD ( } \\
=6) \\
\text { - Age (mean) = } 67.5 \\
\text { yrs (range 65-7I yrs) } \\
\text { - Smoking status: for- } \\
\text { mer }(n=4) \text {; current } \\
(n=2)\end{array}$ & $\begin{array}{l}\text { This study discussed that } \\
\text { social stigma (related to } \\
\text { preconceptions about } \\
\text { COPD regarded as } \\
\text { pulmonary tuberculosis) and } \\
\text { smoking-related issues (eg, } \\
\text { smoking cessation) could } \\
\text { inhibit study participants } \\
\text { from adapting and managing } \\
\text { COPD. }\end{array}$ & $76.7 \%$ \\
\hline $\begin{array}{l}\text { Kosteli, Heneghan, } \\
\text { Roskell, Williams, } \\
\text { Adab, Dickens, } \\
\text { Enocson, } \\
\text { Fitzmaurice, Jolly } \\
\text { and Jordan, }{ }^{40} 2017 \text {, } \\
\text { United Kingdom }\end{array}$ & $\begin{array}{l}\text { To identify barriers and } \\
\text { enablers of physical activity } \\
\text { (PA) engagement for people } \\
\text { with COPD }\end{array}$ & $\begin{array}{l}\text { Qualitative, } \\
\text { descriptive study }\end{array}$ & $\begin{array}{l}\text { People with COPD (N } \\
=26) \\
\text { - } \text { Age (range) = 50-89 } \\
\text { yrs } \\
\text { - Smoking status: not } \\
\text { reported }\end{array}$ & $\begin{array}{l}\text { This study discussed health } \\
\text { related issues (fatigue, } \\
\text { mobility problems, breathing } \\
\text { issues), the psychological } \\
\text { impact of the physical } \\
\text { limitations associated with } \\
\text { their COPD } \\
\text { (embarrassment, fear, } \\
\text { frustration/disappointment), } \\
\text { attitudinal (feeling in control } \\
\text { of their condition, PA } \\
\text { perception, older age } \\
\text { perception), and } \\
\text { motivational issues as the } \\
\text { main barriers to physical } \\
\text { activity engagement. } \\
\text { Motivation, attitudes, self- } \\
\text { regulation, and performance } \\
\text { accomplishments were } \\
\text { identified as the main } \\
\text { enabling factors. }\end{array}$ & $76.7 \%$ \\
\hline $\begin{array}{l}\text { Lindgren, Storli and } \\
\text { Wiklund-Gustin, }{ }^{41} \\
\text { 2014, Sweden }\end{array}$ & $\begin{array}{l}\text { To illuminate patients' lived } \\
\text { experiences of going } \\
\text { through the process of being } \\
\text { diagnosed with COPD }\end{array}$ & $\begin{array}{l}\text { Qualitative, } \\
\text { phenomenological } \\
\text { study }\end{array}$ & $\begin{array}{l}\text { People with mild to } \\
\text { moderate COPD (N } \\
=8) \\
\text { - Age (range) }=60-74 \\
\text { yrs } \\
\text { - Smoking status: former } \\
(n=7) ; \text { current }(n=1)\end{array}$ & $\begin{array}{l}\text { The process of being } \\
\text { diagnosed with COPD was } \\
\text { confusing for study } \\
\text { participants. Shame and guilt } \\
\text { related to the diagnosis and } \\
\text { the idea of a chronic disease } \\
\text { interfered with the } \\
\text { acceptance of being } \\
\text { diagnosed with COPD. }\end{array}$ & $80.0 \%$ \\
\hline
\end{tabular}

(Continued) 
Table I (Continued).

\begin{tabular}{|c|c|c|c|c|c|}
\hline $\begin{array}{l}\text { Author, Year, } \\
\text { Location }\end{array}$ & Research Aim & Study Design & $\begin{array}{l}\text { Sample } \\
\text { Characteristics }\end{array}$ & Main Findings & $\begin{array}{l}\text { Methodological } \\
\text { Quality }\end{array}$ \\
\hline $\begin{array}{l}\text { Lundell, Wadell, } \\
\text { Wiklund and } \\
\text { Tistad, }{ }^{42} 2020 \text {, } \\
\text { Sweden }\end{array}$ & $\begin{array}{l}\text { To explore how people with } \\
\text { COPD experience COPD- } \\
\text { related interactions with } \\
\text { healthcare professionals in } \\
\text { primary care and how it } \\
\text { influences their self- } \\
\text { management }\end{array}$ & $\begin{array}{l}\text { Qualitative study } \\
\text { using grounded } \\
\text { theory }\end{array}$ & $\begin{array}{l}\text { People with COPD }(\mathrm{n}= \\
\text { 13) } \\
\text { - Age (mean) = } 69 \mathrm{yrs} \\
\text { (range } 48-80 \text { yrs) } \\
\text { - Smoking status: for- } \\
\text { mer ( } n=7) \text {; current } \\
(n=6)\end{array}$ & $\begin{array}{l}\text { Positive view of life and } \\
\text { mutually respectful } \\
\text { relationship of people with } \\
\text { COPD with healthcare } \\
\text { professionals empowered } \\
\text { and facilitated acceptance } \\
\text { and management of their } \\
\text { COPD. Experiences of being } \\
\text { deprioritized, fear, and } \\
\text { stigma disempowered and } \\
\text { inhibited people with COPD } \\
\text { from seeking appropriate } \\
\text { medical help as well as made } \\
\text { them pass up a chance to } \\
\text { get sufficient support from } \\
\text { their healthcare } \\
\text { professionals. }\end{array}$ & $83.3 \%$ \\
\hline $\begin{array}{l}\text { Svedsater, Roberts, } \\
\text { Patel, Macey, Hilton } \\
\text { and Bradshaw, }{ }^{43} \\
2017, \text { United } \\
\text { Kingdom }\end{array}$ & $\begin{array}{l}\text { To understand patients' } \\
\text { perspectives on asthma or } \\
\text { COPD and identify factors } \\
\text { that can determine } \\
\text { treatment benefits }\end{array}$ & $\begin{array}{l}\text { Qualitative, } \\
\text { descriptive study }\end{array}$ & $\begin{array}{l}\text { Patient group } \\
\text { i) Asthma }(n=39) \\
\text { - Age (mean) = } 35.5 \\
\text { yrs } \\
\text { - Smoking status: never } \\
(n=26) \text {; former ( } n \\
=8) \text {; current }(n=5) \\
\text { ii) COPD }(n=33) \\
\text { - Age (mean) = 60.2 } \\
\text { yrs } \\
\text { - Smoking status: never } \\
(n=15) ; \text { former }(n= \\
\text { I3); current }(n=5) \\
\text { Clinical experts }(n=4)\end{array}$ & $\begin{array}{l}\text { Individuals with asthma or } \\
\text { COPD tended to focus on } \\
\text { substantial quality of life } \\
\text { limitations due to their } \\
\text { condition, rather than } \\
\text { symptoms per se. Improved } \\
\text { sleep, speed of action, and } \\
\text { length of relief were the } \\
\text { most frequently reported } \\
\text { factors for the ideal } \\
\text { treatment. }\end{array}$ & $76.7 \%$ \\
\hline
\end{tabular}

Abbreviation: COPD, chronic obstructive pulmonary disease.

People with COPD described enacted stigma as the way others look at you, the things they say and do. ${ }^{28,31}$ Three studies described that people with COPD feel uncomfortable with their friends' and family members' reactions to "using the inhalers in public"31 and "the odor of smoke," ${ }^{38}$ and they do not like it when a lot of time is spent "focusing on smoking in private conversations." $" 36$

People with COPD described felt stigma as feeling "underprivileged, sometimes exploited" with regard to the tobacco-free campaigns ${ }^{36}$ and "discredited because of value judgements regarding their diagnosis" in their social circles $^{36}$ and in healthcare contacts. ${ }^{42}$ In four studies, people with COPD reported that societal attitudes toward smoking and smokers were unfair, and they attempted to reframe or contextualize their smoking behavior by explaining that smoking was accepted in society when they started smoking. ${ }^{28,36,37,41}$

Substantial evidence suggests that people with COPD also internalize stigma by adopting negative beliefs about themselves and that they anticipate stigma in specific situations. Seven studies described people with COPD as excessively conscious of their appearance with regard to visible symptoms, smelling like cigarette smoke, or using equipment such as medication inhalers and oxygen delivery systems. ${ }^{28,31,33,35,37,38,40}$ In addition, four studies reported that people with COPD also anticipate stigma: for example, they anticipate being singled out for 
unwanted attention if they smell like smoke or use a medical device in public..$^{31,33,35,38}$

\section{Moderating Factors}

In the included studies, we identified evidence for three factors that moderate the magnitude and effects of COPDrelated stigma: concealability or visibility of the disease, origin of the disease, and people's perception of the disease, described as illness perception.

\section{Visibility of COPD}

The most commonly reported issues were the use of medical devices and COPD symptoms such as coughing and shortness of breath, both of which are highly visible signs that can trigger stigma processes. ${ }^{31,35,40,43}$

\section{Origin of COPD and/or Responsibility for the Disease}

Seven studies described COPD as a self-inflicted disease, so people with COPD are deemed to bear responsibility for their disease ${ }^{28,30-32,36,37,41}$ basically, they have no one to blame but themselves. This major component of COPDrelated stigma is that the person with COPD is the problem, which reduces others' tendency to empathize and appreciate their challenges.

\section{Illness Perception}

Four studies described beliefs that people with COPD have about their disease. ${ }^{32,37,38,41}$ They reported that COPD is a humiliating disease, so they hide it. ${ }^{32}$ They felt loathing for COPD symptoms ${ }^{37,38}$ and for being labeled as a COPD patient or a smoker. ${ }^{41}$ In addition, it was noted that the public image of COPD aggravates their stigma experiences. ${ }^{36}$

\section{Individual-Level Responses}

The research included in this review focused more on individual-level responses to stigmatizing behavior than on other constructs of Major et al's conceptual model, ${ }^{24}$ which recognizes three different domains of response-affective, cognitive, and behavioral.

\section{Affective Responses}

Eight studies reported that having a self-inflicted disease generates feelings of self-blame, shame, and guilt in people with COPD. ${ }^{28,30,31,33,34,36,37,41}$ Six studies found that using a medical device (eg, inhaler or oxygen) and experiencing COPD symptoms (eg, breathlessness or uncontrollable coughing) in public cause feelings of embarrassment. ${ }^{28,31,33,35,40,43}$ Three studies pointed out that people with COPD suffer from negative emotions (eg, feelings of being losers, anger, grief, fear, anxiety, depression, sadness, uselessness, or hopelessness) because their smoking resulted in an incurable disease. ${ }^{36,41,43}$ Some people with COPD are traumatized ${ }^{31}$ or suffer from painful stress ${ }^{36}$ after experiencing stigma. Two studies reported that people with COPD face a threat of low self-worth and self-esteem. ${ }^{37,41}$ Two studies reported that people with COPD express disappointment with the public image of COPD as a self-inflicted disease of heavy smokers. ${ }^{36,41}$ In addition, people with COPD who continue smoking have feelings of being a failure or a loser. ${ }^{34,36,41,42}$

\section{Behavioral Responses}

One study ${ }^{36}$ found that people with COPD who continue smoking are at higher risk of isolation. Two studies ${ }^{33,35}$ reported that using a medical device (eg, oxygen) and experiencing COPD symptoms (eg, coughing and phlegm) in public can give rise to self-conscious emotions and ensuing self-isolation. Other studies ${ }^{37-39,41}$ noted that others' judgmental behaviors could lead people with COPD to avoid contact with the outside world. Seven studies ${ }^{28,31,32,35,36,41,42}$ reported that people with COPD strive daily to hide their diagnosis, symptoms and treatments, physical impairment/disabilities, or failure to abstain from smoking. Three studies reported that people with COPD attempt to minimize stigma experiences by adjusting or avoiding activities ${ }^{30,37}$ or defending their independence and contributions to society. ${ }^{28,37}$ Furthermore, people with COPD are reluctant to seek help due to fear of being judged or blamed by others, or being ashamed. ${ }^{30,36,41,42}$ A guilty conscience also makes it difficult for people with COPD to comply with doctor's advice to quit smoking. ${ }^{41}$

Three studies found that people with COPD use coping strategies to reduce the negative emotions associated with stigma experiences. For example, some will try to maintain their normal routine to preserve functional capacity. ${ }^{33}$ Some will reveal their smoking habits to other ${ }^{34}$ and quit smoking. ${ }^{36}$ Another study reported that sharing with others who are understanding and empathetic helps alleviate feelings of guilt and improves self-esteem. ${ }^{41}$

\section{Cognitive Responses}

Two studies described that some people with COPD strive to find different causes of their disease other than their smoking behavior. ${ }^{36,39}$ Four studies described that some people with COPD tend to suppress their feelings of guilt, 
shame, and/or embarrassment, ${ }^{32,43}$ and their concerns, ${ }^{31}$ some even deny their diagnosis. ${ }^{41}$

\section{Social/Community-Level Exclusion}

Three studies described that healthcare providers reprimanded people with COPD for their smoking. ${ }^{31,34,36}$ People with COPD reported that their doctors were apathetic about their care and showed little interest once they became aware of their smoking. ${ }^{35,37}$ Another study reported that people with COPD have few opportunities for employment because of the potential negative impact on employers' costs for health insurance. ${ }^{31}$

\section{Discussion}

COPD-related stigma is a complex phenomenon and rests on the inextricable connection between COPD and smoking. Major et al's conceptual model of the effects of stigma processes on health ${ }^{24}$ was used to organize the data. The reviewed research provides a rich description of the multiple domains of stigma including stigma processes, moderating factors, and individual and social/community responses to stigma, but it does not fully describe the negative impact on health. According to the framework, stigma ultimately impacts health, mostly through its negative effects on affective, cognitive and behavioral responses, but we found no research that explored the relationship between stigma and health or between the individual-level responses to stigma and health.

Separate from the framework, the research describes a wide range of stigma experiences, but some elements were repeated more frequently than others. The strong and common belief that COPD is a self-inflicted disease generates feelings of self-blame, shame, and guilt. In the same vein, people with COPD are very conscious of their appearance and embarrassed by visible symptoms such as dyspnea, coughing, and medical equipment such as inhalers and delivery systems. People with COPD strive to hide their diagnosis, symptoms, treatments, physical impairment/disabilities and/or their failure to abstain from smoking. These issues were described repeatedly throughout multiple studies.

Although we searched specifically for COPD-related stigma, two-thirds $(n=8)^{30,33-35,37-43}$ of the included studies described COPD-related stigma experiences that were embedded within the broader topic of living with COPD and did not investigate the phenomenon of stigma in great depth. In these eight studies, stigma-related experiences were described as part of the lived experience of COPD. This is similar to other stigmatized chronic conditions such as diabetes ${ }^{44}$ and lung cancer. ${ }^{45}$ Having a chronic illness can be regarded as a spoiled identity ${ }^{46}$ in which people experience feelings of shame, isolation, and lack of control over their lives. ${ }^{47}$ Because the experience of stigma is common for many people with chronic illness, its burden should not be underestimated and/or ignored, especially considering its potential adverse effects on health and well-being. ${ }^{48}$

The negative impact of COPD-related stigma on psychosocial domains is clear, while its effects on self-care behaviors, such as adherence and help-seeking, are less clear and require further study. The potential negative effects on treatment adherence to prescribed inhaled medication and supplemental oxygen were noted but not explored in depth. Similarly, it was noted that healthcare providers' stigmatizing behavior has the potential to negatively affect help-seeking behavior, but, again, the phenomenon was not fully explored. Considering that selfmanagement is a critical element of COPD management, more research is needed in both areas. Earnshaw and Quinn ${ }^{19}$ observed that those who experience stigma from healthcare providers may anticipate greater stigma and have potential risks associated with lower access to healthcare and decreased quality of life. However, the impact of being stigmatized by healthcare providers is not known. More research is needed to understand the phenomenon and its effects on adherence to treatment and other healthrelated outcomes in people with COPD.

A range of COPD-related stigma experiences was described, but we found no evidence describing the prevalence or intensity of this phenomenon in people with COPD. While it is clear that some people with COPD experience substantial stigma, the range of levels of stigma experienced by individuals with COPD and the extent to which it affects them is unclear. The research included in this review documents the importance of COPD-related stigma, but the majority of studies are qualitative in nature with relatively small sample sizes, and further research is needed to establish the prevalence and intensity of COPDrelated stigma.

\section{Limitations}

One limitation of this integrative review is that all the included studies were conducted in high-income countries: ${ }^{49}$ nine European and three North American. While the review reflects diverse aspects of living with COPD and indicates that the existence of COPD-related 
stigma is consistent across these countries, the findings may not be generalizable to other countries. Second, the review only included studies published in English and did not include the gray literature, which may have led to the exclusion of relevant studies.

\section{Conclusion}

Smoking is the primary socially conferred mark of COPD and the evidence documents four stigma processes: enacted stigma, felt stigma, internalized stigma and anticipated stigma. The effects of COPD-related stigma are intensified by the highly visible features of the disease, its self-inflicted nature, and the perceptions of people with COPD that it is humiliating to have COPD. Individual responses to COPD-related stigma include emotional distress, limiting social interactions, issues with treatment adherence, and negative attitudes toward help-seeking. Little is known about the prevalence and intensity of stigmatization and the health effects of stigma in this population.

\section{Abbreviations}

COPD, chronic obstructive pulmonary disease; GOLD, Global Initiative for Chronic Obstructive Lung Disease.

\section{Acknowledgment}

The submission of this manuscript is based on the first author's dissertation. $^{50}$ The authors thank Ms. Celia M. Bridges of the University of Michigan for her thorough editing of the manuscript. The authors thank Health Technology Assessment NIHR HTA programme for allowing to reproduce of the checklists ${ }^{26}$ for assessing methodological quality in this manuscript.

\section{Author Contributions}

All authors contributed to data analysis, drafting or revising the article, have agreed on the journal to which the article will be submitted, gave final approval of the version to be published, and agree to be accountable for all aspects of the work.

\section{Disclosure}

The authors report no conflicts of interest in this work.

\section{References}

1. Van Brakel WH. Measuring health-related stigma - a literature review. Psychol Health Med. 2006;11(3):307-334. doi:10.1080/13548500600 595160
2. Neal C, McGoldrick D, Schear RM. The experience of stigma: impacts and implications. In: Miller KD, Simon M, eds. Global Perspectives on Cancer: Incidence, Care, and Experience [2 Volumes]. Abc-Clio; 2015:41-53:chap 4.

3. Rose S, Paul C, Boyes A, Kelly B, Roach D. Stigma-related experiences in non-communicable respiratory diseases: a systematic review. Chron Respir Dis. 2017;14(3):1479972316680847. doi:10.1177/ 1479972316680847

4. Lippiett KA, Richardson A, Myall M, Cummings A, May CR. Patients and informal caregivers' experiences of burden of treatment in lung cancer and chronic obstructive pulmonary disease (COPD): a systematic review and synthesis of qualitative research. BMJ Open. 2019;9(2):e020515. doi:10.1136/bmjopen2017-020515

5. Wheaton AG, Liu Y, Croft JB, et al. Chronic obstructive pulmonary disease and smoking status-United States, 2017. MMWR Morb Mortal Wkly Rep. 2019;68(24):533. doi:10.15585/mmwr. mm6824a1

6. Evans-Polce RJ, Castaldelli-Maia JM, Schomerus G, Evans-Lacko SE. The downside of tobacco control? Smoking and self-stigma: a systematic review. Soc Sci Med. 2015;145:26-34. doi:10.1016/j. socscimed.2015.09.026

7. Cummings KM, Proctor RN. The changing public image of smoking in the United States: 1964-2014. Cancer Epidemiol Biomarkers Prev. 2014;23(1):32-36. doi:10.1158/1055-9965.EPI-13-0798

8 . The health consequences of smoking -50 years of progress: a report of the surgeon general (U.S. Department of Health and Human Services, Centers for Disease Control and Prevention, National Center for Chronic Disease Prevention and Health Promotion, Office on Smoking and Health); 2014.

9. Bell K, Salmon A, Bowers M, Bell J, McCullough L. Smoking, stigma and tobacco 'denormalization': further reflections on the use of stigma as a public health tool. A commentary on social science \& medicine's stigma, prejudice, discrimination and health special issue (67: 3). Soc Sci Med. 2010;70(6):795-799. doi:10.1016/j. socscimed.2009.09.060

10. Kim SH, Shanahan J. Stigmatizing smokers: public sentiment toward cigarette smoking and its relationship to smoking behaviors. $J$ Health Commun. 2003;8(4):343-367. doi:10.1080/10810730305723

11. Hammond D, Fong GT, Zanna MP, Thrasher JF, Borland R. Tobacco denormalization and industry beliefs among smokers from four countries. Am J Prev Med. 2006;31(3):225-232. doi:10.1016/j. amepre.2006.04.004

12. Farrelly MC, Nonnemaker JM, Watson KA. The consequences of high cigarette excise taxes for low-income smokers. PLoS One. 2012;7(9):e43838. doi:10.1371/journal.pone.0043838

13. Lehto RH. Patient views on smoking, lung cancer, and stigma: a focus group perspective. Eur J Oncol Nurs. 2014;18(3):316-322. doi:10.1016/j.ejon.2014.02.003

14. Jones EE, Farina A, Hastorf AH, Markus H, Miller DT, Scott RA. Social Stigma: The Psychology of Marked Relationships. W. H. Freeman and Company; 1984.

15. Weiner B, Perry RP, Magnusson J. An attributional analysis of reactions to stigmas. J Pers Soc Psychol. 1988;55(5):738. doi:10.1037/ 0022-3514.55.5.738

16. Bass B, Lake E, Elvy C, et al. Smoking-related stigma expressed by physiotherapists toward individuals with lung disease. Physiother Can. 2018;70(1):65-71. doi:10.3138/ptc.2016-98

17. Strang S, Farrell M, Larsson L-O, et al. Experience of guilt and strategies for coping with guilt in patients with severe COPD: a qualitative interview study. $J$ Palliat Care. 2014;30(2):108-115. doi: $10.1177 / 082585971403000206$

18. Ágh T, Dömötör P, Bártfai Z, Inotai A, Fujsz E, Mészáros Á. Relationship between medication adherence and health-related quality of life in subjects with COPD: a systematic review. Respir Care. 2015;60(2):297-303. doi:10.4187/respcare. 03123 
19. Earnshaw VA, Quinn DM. The impact of stigma in healthcare on people living with chronic illnesses. J Health Psychol. 2012;17 (2):157-168. doi:10.1177/1359105311414952

20. Kinsler JJ, Wong MD, Sayles JN, Davis C, Cunningham WE. The effect of perceived stigma from a health care provider on access to care among a low-income HIV-positive population. AIDS Patient Care STDS. 2007;21(8):584-592. doi:10.1089/apc.2006.0202

21. Taft TH, Keefer L. A systematic review of disease-related stigmatization in patients living with inflammatory bowel disease. Clin Exp Gastroenterol. 2016;9:49. doi:10.2147/CEG.S83533

22. Yan H, Li X, Li J, et al. Association between perceived HIV stigma, social support, resilience, self-esteem, and depressive symptoms among HIV-positive men who have sex with men (MSM) in Nanjing, China. AIDS Care. 2019;31(9):1069-1076. doi:10.1080/ 09540121.2019.1601677

23. Mickelson KD. Perceived stigma, social support, and depression. Pers Soc Psychol Bull. 2001;27(8):1046-1056. doi:10.1177/ 0146167201278011

24. Major B, Dovidio JF, Link BG. The Oxford Handbook of Stigma, Discrimination, and Health. Oxford University Press; 2018.

25. Whittemore $\mathrm{R}$, Knafl $\mathrm{K}$. The integrative review: updated methodology. J Adv Nurs. 2005;52(5):546-553. doi:10.1111/j.13652648.2005.03621.x

26. Shaw C, McNamara R, Abrams K, et al. Systematic review of respite care in the frail elderly. Health Technol Assess. 2009;13(20):1-246. doi: $10.3310 /$ hta 13200

27. Sandelowski M, Leeman J. Writing usable qualitative health research findings. Qual Health Res. 2012;22(10):1404-1413. doi:10.1177/ 1049732312450368

28. Harrison SL, Robertson N, Goldstein RS, Brooks D. Exploring self-conscious emotions in individuals with chronic obstructive pulmonary disease: a mixed-methods study. Chron Respir Dis. 2017;14 (1):22-32. doi:10.1177/1479972316654284

29. NVivo. Version 12. QSR International Pty Ltd.; 2018. Available from: https://www.qsinternational.com/nvivo-qualitative-data-analysissoftware/home. Accessed April 30, 2021.

30. Arne M, Emtner M, Janson S, Wilde-Larsson B. COPD patients' perspectives at the time of diagnosis: a qualitative study. Prim Care Respir J. 2007;16(4):215-221. doi:10.3132/pcrj.2007.00033

31. Berger BE, Kapella MC, Larson JL. The experience of stigma in chronic obstructive pulmonary disease. West J Nurs Res. 2011;33 (7):916-932. doi:10.1177/0193945910384602

32. Bragadottir GH, Halldorsdottir BS, Ingadottir TS, Jonsdottir H. Patients and families realising their future with chronic obstructive pulmonary disease-A qualitative study. J Clin Nurs. 2018;27(1/ 2):57-64. doi:10.1111/jocn.13843

33. Earnest MA. Explaining adherence to supplemental oxygen therapy. J Gen Intern Med. 2002;17(10):749-755. doi:10.1046/j.1525-1497.20 02.20218.x

34. Fusi-Schmidhauser T, Froggatt K, Preston N. Living with advanced chronic obstructive pulmonary disease: a qualitative interview study with patients and informal carers. COPD. 2020;17(4):410-418. doi: $10.1080 / 15412555.2020 .1782867$

35. Gysels M, Higginson IJ. Access to services for patients with chronic obstructive pulmonary disease: the invisibility of breathlessness. $J$ Pain Symptom Manage. 2008;36(5):451-460. doi:10.1016/j. jpainsymman.2007.11.008
36. Halding AG, Heggdal K, Wahl A. Experiences of self-blame and stigmatisation for self-infliction among individuals living with COPD. Scand J Caring Sci. 2011;25(1):100-107. doi:10.1111/ j.1471-6712.2010.00796.x

37. Harrison SL, Robertson N, Apps LC, Steiner M, Morgan MD, Singh SJ. "We are not worthy"-understanding why patients decline pulmonary rehabilitation following an acute exacerbation of COPD. Disabil Rehabil. 2015;37(9):750-756. doi:10.3109/09638288.2014. 939770

38. Jonsdottir R, Jonsdottir H. The experience of women with advanced chronic obstructive pulmonary disease of repeatedly relapsing to smoking. Scand J Caring Sci. 2007;21(3):297-304. doi:10.1111/ j.1471-6712.2007.00472.x

39. Kim K, Ko JW, Choi S. Qualitative analysis of the disease experience of korean older men with chronic obstructive pulmonary disease. J Gerontol Nurs. 2020;46(2):49-56. doi:10.3928/00989134-202001 08-02

40. Kosteli M-C, Heneghan NR, Roskell C, et al. Barriers and enablers of physical activity engagement for patients with COPD in primary care. Int J Chron Obstruct Pulmon Dis. 2017;12:1019. doi:10.2147/COPD. S119806

41. Lindgren S, Storli SL, Wiklund-Gustin L. Living in negotiation: patients' experiences of being in the diagnostic process of COPD. Int J Chron Obstruct Pulmon Dis. 2014;9:441. doi:10.2147/COPD. S60182

42. Lundell S, Wadell K, Wiklund M, Tistad M. Enhancing confidence or coping with stigma in an ambiguous interaction with primary care: a qualitative study of people with COPD. COPD. 2020;17:533-542.

43. Svedsater H, Roberts J, Patel C, Macey J, Hilton E, Bradshaw L. Life impact and treatment preferences of individuals with asthma and chronic obstructive pulmonary disease: results from Qualitative Interviews and Focus Groups. Adv Ther. 2017:1-16.

44. Schabert J, Browne JL, Mosely K, Speight J. Social stigma in diabetes. Patient. 2013;6(1):1-10. doi:10.1007/s40271-012-0001-0

45. Chambers SK, Dunn J, Occhipinti S, et al. A systematic review of the impact of stigma and nihilism on lung cancer outcomes. BMC Cancer. 2012;12(1):184. doi:10.1186/1471-2407-12-184

46. Goffman E. Stigma: Notes on the Management of Spoiled Identity. Simon and Schuster; 1963.

47. Charmaz K. Experiencing chronic illness. In: Albrecht GL, Fitzpatrick, Ray, \& Scrimshaw, Susan C., ed. Handbook of Social Studies in Health and Medicine. SAGE Publications; 2000:277-292: chap 2.6.

48. Pachankis JE, Hatzenbuehler ML, Wang K, et al. The burden of stigma on health and well-being: a taxonomy of concealment, course, disruptiveness, aesthetics, origin, and peril across 93 stigmas. Pers Soc Psychol Bull. 2018;44(4):451-474. doi:10.1177/01461672177 41313

49. United Nations. World economic situation and prospects 2020. United Nations publication. Accessed April 06, 2021. https://www. un.org/development/desa/dpad/publication/world-economic-situa tion-and-prospects-2020/https://www.un.org/development/desa/dpad/ wp-content/uploads/sites/45/WESP2020_FullReport.pdf.

50. Woo S Developing and Evaluating a Stigma Scale for People with COPD [Dissertation]. University of Michigan; 2019. Available from: https://deepblue.lib.umich.edu/handle/2027.42/ 153482. Accessed February 17, 2021. 


\section{Publish your work in this journal}

The International Journal of COPD is an international, peer-reviewed journal of therapeutics and pharmacology focusing on concise rapid reporting of clinical studies and reviews in COPD. Special focus is given to the pathophysiological processes underlying the disease, intervention programs, patient focused education, and self management protocols. This journal is indexed on PubMed Central, MedLine and CAS. The manuscript management system is completely online and includes a very quick and fair peer-review system, which is all easy to use. Visit http://www.dovepress.com/testimonials.php to read real quotes from published authors. 